Acta vet. scand. $1978,19,479-486$.

From the Department of Pharmacology and Toxicology, Royal Veterinary and Agricultural University, Copenhagen, Denmark.

\title{
ENDOTOXIN INDUCED CHANGES IN THE PHARMACOKINETICS OF WARFARIN IN RABBITS*
}

\author{
By \\ Ole Ladefoged
}

\begin{abstract}
LADEFOGED, 0.: Endotoxin induced changes in the pharmacokinetics of warfarin in rabbits. Acta vet. scand. 1978, 19, 479-486. The action of bacterial endotoxin on the pharmacokinetics of warfarin was investigated in rabbits injected with bacterial endotoxin from E. coli. High doses of endotoxin were able to change the kinetics of warfarin in rabbits by changing its volume of distribution. It is not possible to conclude whether the changes in elimination rate of warfarin in rabbits were mediated through changes in liver blood flow or through impairment of the metabolic capacity of the liver cells.
\end{abstract}

warfarin; endotoxin shock; pharmacokinetics; rabbits; pigs.

More and more attention has been drawn to the pharmacokinetics of drug in pathological and abnormal physiological states during the last few years (Kato 1977). The influence of dysfunctions in the liver and the kidney on drug pharmacokinetics has mainly been investigated for the obvious reason that these two organs are the most important for the disposition of drugs.

The incidence of and mortality from gram-negative bacterial sepsis is increasing in humans (Wolff \& Bennett 1974), and may be so also in the veterinary clinic. The mortality associated with infections caused by gram-negative bacteria is considered to be related to the endotoxins. Patients with endotoxemia need an intensive treatment with different sorts of drugs. The occurrence of endotoxemia in infectious diseases poses potential thera-

* The work was supported by the Danish Agricultural and Veterinary Research Council. 
peutic problems if endotoxin alters the pharmacokinetics of drugs administered for the treatment of the infections. The implications of bacterial endotoxins in disposition of some drugs have recently been reported (Song et al. 1972, Elin et al. 1975, Ladefoged 1977, 1978). The aim of the present investigation was to clarify whether drug pharmacokinetics would be changed in rabbits with circulation disturbances caused by endotoxin injections. Four experiments were also performed to investigate if the pharmacokinetics could be changed in pigs after single injections of endotoxin. Warfarin, a compound mainly metabolized in the liver and highly bound to plasma albumin (Bachmann \& Shapiro 1977), was used as test substance.

\section{MATERIALS AND METHODS}

Twelve clinically healthy male rabbits weighing $3-4 \mathrm{~kg}$ were used in the experiments. A control experiment was performed for the determination of the pharmacokinetic parameters. Warfarin, $3 \mathrm{mg} / \mathrm{kg} \mathrm{b}$. wt., was injected intravenously into the left ear, and 10-14 venous blood samples $(1 \mathrm{ml})$ were taken from a vein in the right ear in the time range of $5 \mathrm{~min}$. to $400-600$ min. after the injection of warfarin. One week later endotoxin from E. coli (Sigma ${ }^{\circledR}$ ) was injected to eight rabbits in an amount of $0.5 \mu \mathrm{g} / \mathrm{kg}$ b. wt. Four rabbits were injected with a dose of endotoxin correspondent to $0.2 \mu \mathrm{g} / \mathrm{kg}$ b. wt. One hour after the endotoxin administration $3 \mathrm{mg} / \mathrm{kg} \mathrm{b}$. wt. of warfarin was injected and blood was sampled as described above.

In the experiments on pigs four female pigs of Danish Landrace weighing $23-30 \mathrm{~kg}$ were used. Two animals were injected intravenously with $3 \mathrm{mg} / \mathrm{kg}$ of warfarin. The two other pigs were dosed with $1 \mathrm{mg} / \mathrm{kg} \mathrm{b}$. wt. The injection of warfarin was followed by blood sampling in the time range of $5 \mathrm{~min}$. to $160 \mathrm{~min}$. After that time endotoxin, $2.5 \mu \mathrm{g} / \mathrm{kg}$ b. wt., was injected intravenously, and blood sampling continued for further $270 \mathrm{~min}$.

Warfarin was determined in the plasma by means of a spectrofluorometric method described elsewhere (Ladefoged 1979). The two-compartment model:

$\mathrm{C}_{\mathrm{t}}=\mathrm{A} \cdot \mathrm{e}^{-\alpha \mathrm{t}}+\mathbf{B} \cdot \mathrm{e}^{-\beta \mathrm{t}}$,

with central compartment $\left(\mathrm{V}_{1}\right)$, peripheral compartment $\left(\mathrm{V}_{2}\right)$, distribution rate constants $\left(\mathrm{k}_{12}, \mathrm{k}_{21}\right)$ and elimination rate con- 
stant $\left(\mathrm{k}_{\mathrm{e}}\right)$ was used to calculate the pharmacokinetic parameters in the experiments with the rabbits.

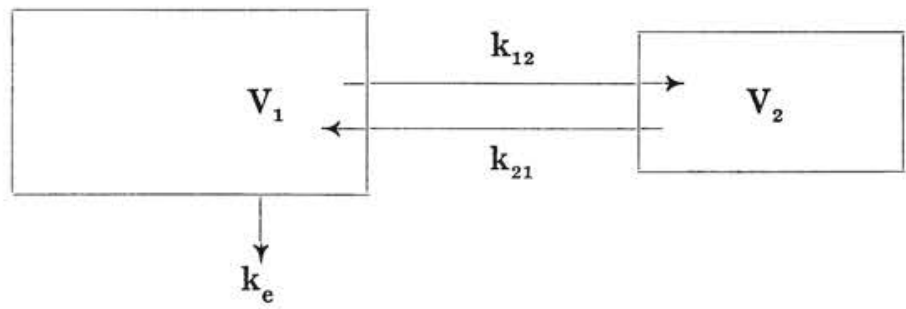

The non-linear iterative curve fitting computer program, which has been described by Ladefoged (1975), was used for the calculation of the pharmacokinetic parameters.

\section{RESULTS}

The averages of the pharmacokinetic parameters of warfarin from the control experiment in rabbits are shown in Table 1.

As seen from Figs. 1, 2 and 3 the two-compartment model fits well to the plasma concentration versus time data in the control experiments. It is seen from the figures that the theoretically calculated plasma concentration deviates only a few $\mu$ from the observed values. Treatment of the rabbits with endotoxin changed the pharmacokinetic parameters in some rabbits as seen from Figs. 1, 2 and 3. It was not possible to fit the two-compartment model to all the data from the experiments with endotoxin injected rabbits. Therefore, all the log plasma concentrations versus time curves for the 12 rabbits are shown in Figs. 1, 2 and 3. The effect of endotoxin on the plasma concentration versus time curve of warfarin is not only dependent on the dose of endotoxin but also related to the response of the rabbits to the endotoxin. The greatest change in the kinetics of warfarin is seen in the

Table 1. Pharmacokinetic parameters of warfarin in control rabbits. The results given are the mean of the control experiments \pm s.e.m.

\begin{tabular}{lrrrrrrrrrr}
\hline & $\begin{array}{c}\mathrm{A} \\
\mu \mathrm{g} / \mathrm{ml}\end{array}$ & $\begin{array}{c}\alpha \\
\mathrm{min}^{-1}\end{array}$ & $\begin{array}{c}\mathrm{B} \\
\mu \mathrm{g} / \mathrm{ml}\end{array}$ & $\begin{array}{c}\beta \\
\mathrm{min}^{-1}\end{array}$ & $\begin{array}{c}\mathrm{k}_{21} \\
\mathrm{~min}^{-1}\end{array}$ & $\begin{array}{c}\mathrm{k}_{\mathrm{e}} \\
\mathrm{min}^{-1}\end{array}$ & $\begin{array}{c}\mathrm{k}_{12} \\
\mathrm{~min}^{-1}\end{array}$ & $\begin{array}{c}\mathrm{V}_{1} \\
1 / \mathrm{kg}\end{array}$ & $\begin{array}{c}\mathrm{V}_{2} \\
1 / \mathrm{kg}\end{array}$ & $\begin{array}{c}\mathrm{Vd}_{\mathrm{ss}} \\
1 / \mathrm{kg}\end{array}$ \\
\hline$\overline{\mathrm{x}}$ & 10.1 & 0.072 & 21.6 & 0.0022 & 0.0497 & 0.0032 & 0.021 & 0.100 & 0.041 & 0.140 \\
\pm s.e.m. & 1.0 & 0.010 & 1.4 & 0.0001 & 0.0068 & 0.0002 & 0.0036 & 0.007 & 0.003 & 0.009 \\
\hline
\end{tabular}



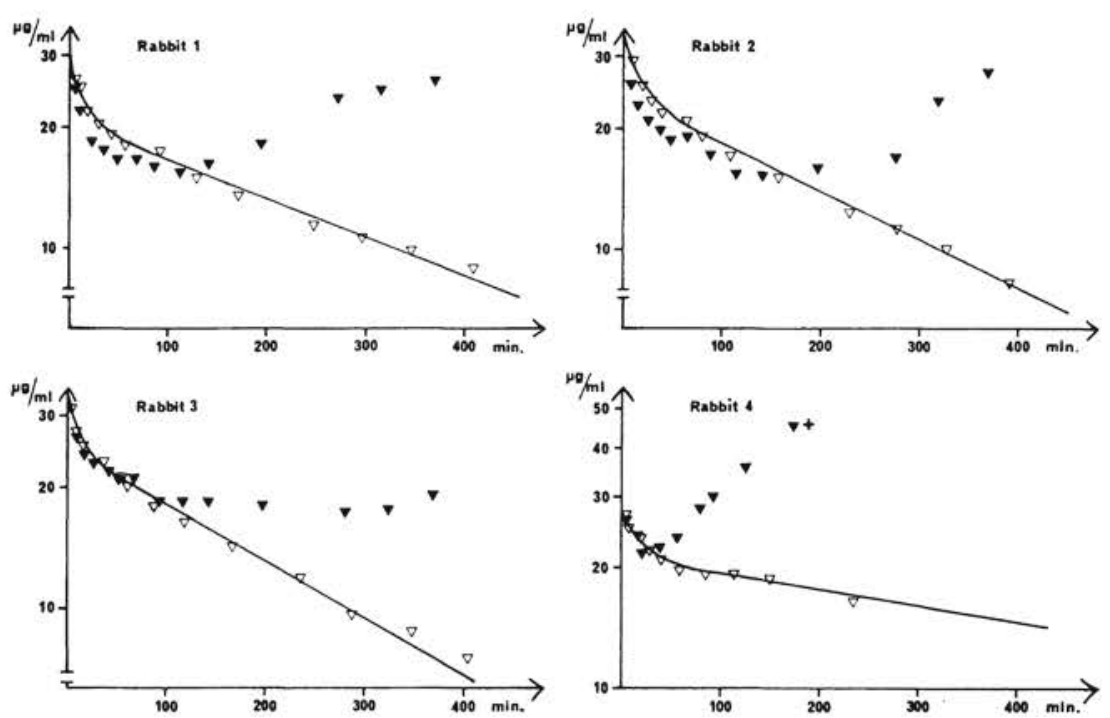

F i g u r e 1. Warfarin concentration $(\mu \mathrm{g} / \mathrm{ml})$ in plasma as a function of time (min.) after intravenous injection of $3 \mathrm{mg} / \mathrm{kg} \mathrm{b}$. wt. The curves represent four control experiments $(\nabla)$ and the results from experiments with the same four rabbits after endotoxin injection $(0.5 \mu \mathrm{g} / \mathrm{kg}$ b. wt.) ( $\boldsymbol{\nabla})$. All the rabbits died within $24 \mathrm{hrs}$. (One rabbit $(+)$ died during the sampling time).

rabbits in which the endotoxin caused severe intoxication, and when the rabbits died from shock within $24 \mathrm{hrs}$. after the endotoxin injection (Fig. 1). In all the rabbits which died, lesions characteristic of endotoxin shock i.e. "shock lung" and edema and hemorrhagic ulcerations in the gastrointestinal tract were found. In the surviving rabbits, less changes in disposition of warfarin were seen (Fig. 2), and at dose level $0.2 \mu \mathrm{g} / \mathrm{kg} \mathrm{b}$. wt. of endotoxin two rabbits handled warfarin very similar to what could be seen in the control experiment (Fig. 3).

Endotoxin did not cause shock in the pigs, and all the pigs survived in spite of the 10 times higher dose used. No differences in the $\beta$ slopes calculated before and after the endotoxin injections or in the calculated volume of distribution could be shown. Just after the endotoxin injection a short rise in plasma concentration of warfarin occurred. This phenomenon was seen in all the pigs. 

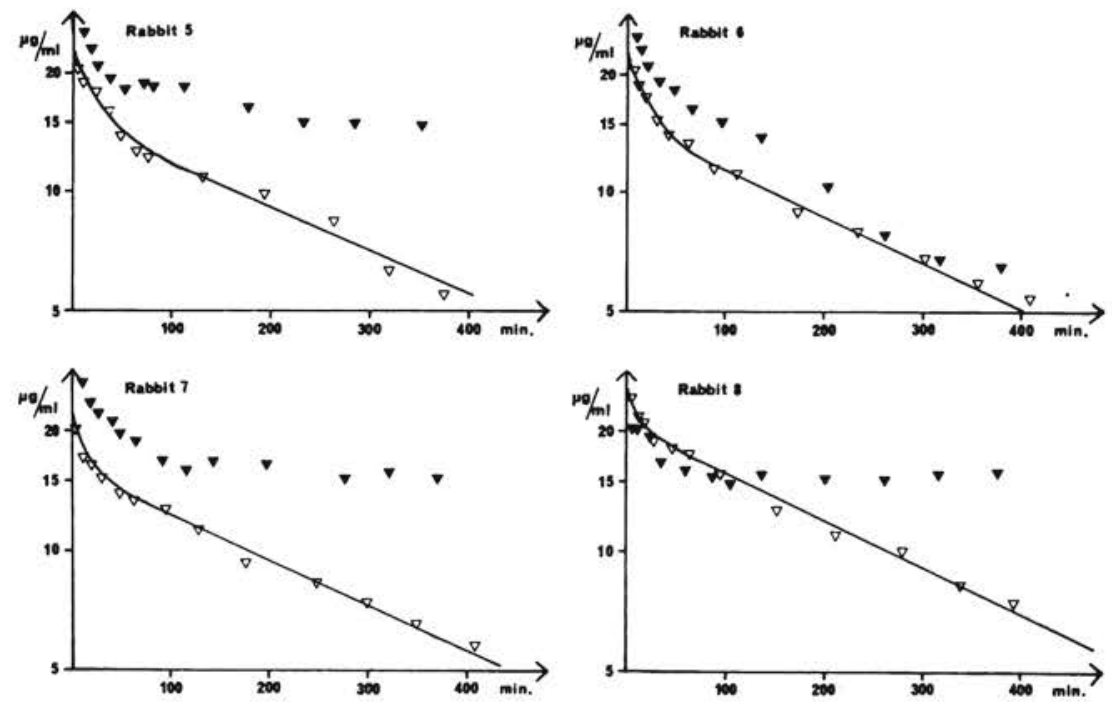

F $1 \mathrm{~g} \mathrm{u} \mathrm{re} \mathrm{2.} \mathrm{Warfarin} \mathrm{concentration}(\mu \mathrm{g} / \mathrm{ml})$ in plasma as a function of time (min.) after intravenous injection of $3 \mathrm{mg} / \mathrm{kg} \mathrm{b}$. wt. The curves represent four control experiments $(\nabla)$ and the results from experiments with the same four rabbits after endotoxin injection $(0.5 \mu \mathrm{g} / \mathrm{kg}$ b. wt.) ( $\boldsymbol{\nabla})$. All the rabbits survived.

\section{DISCUSSION}

The results of the present experiments in rabbits show that the pharmacokinetics of warfarin is influenced by high doses of endotoxin. It seems to be the circulation disturbances as described by others (Landy \& Braun 1964) which are responsible for the changes in the pharmacokinetics, since the greatest changes are seen in the rabbits dying from endotoxin induced shock. Similar changes in the pharmacokinetics of warfarin are obvious in the two rabbits injected with $0.2 \mu \mathrm{g} / \mathrm{kg} \mathrm{b}$. wt. of endotoxin, while two others getting the same dose did not get shock and did not show changes in kinetic parameters. Little is known about pharmacokinetics of drugs in serious illnesses with severe circulation disturbances, and this holds thrue in both animal and man, nor are the pharmacokinetics of drugs in the dying patient or animals well known. The present results indicate that in severe disease states the pharmacokinetic of a drug may change and in patients given repeated doses of drugs overdosing or even toxic plasma concentration might well occur. 

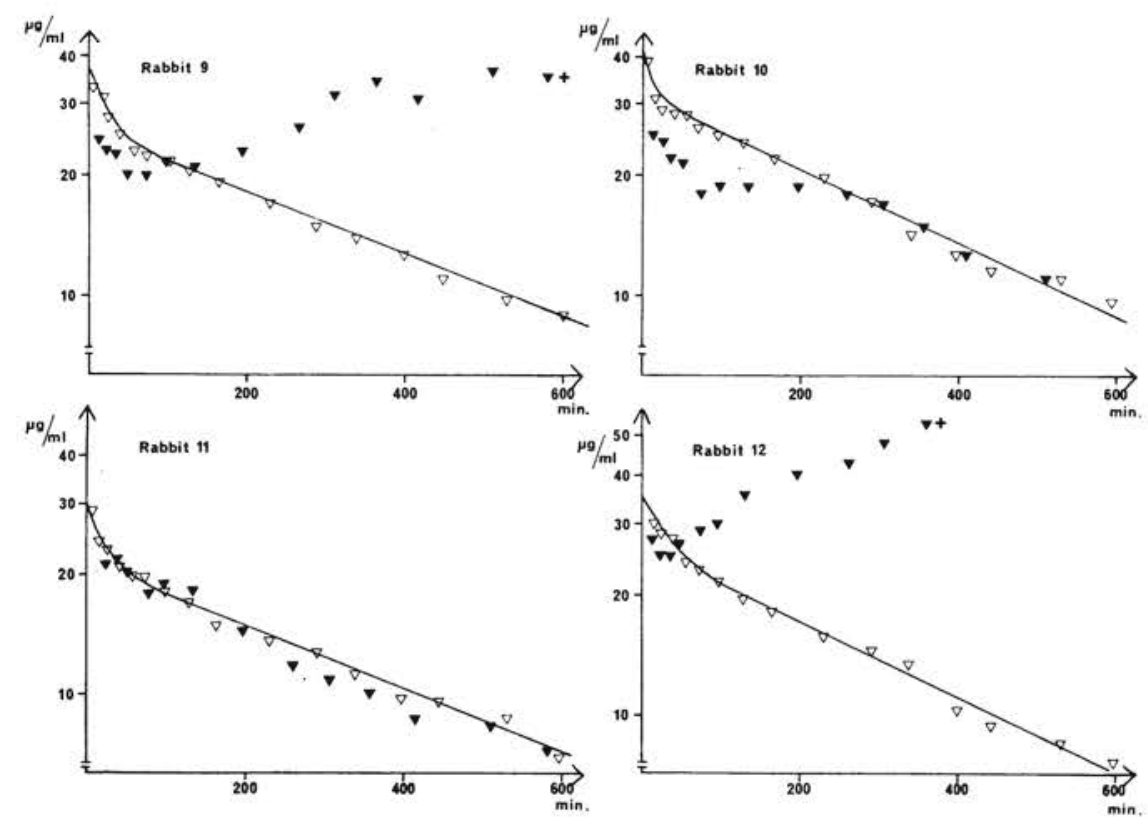

F ig u re 3. Warfarin concentration $(\mu \mathrm{g} / \mathrm{ml})$ in plasma as a function of time (min.) after intravenous injection of $3 \mathrm{mg} / \mathrm{kg} \mathrm{b}$. wt. The curves represent four control experiments $(\nabla)$ and the results from experiments with the same four rabbits after endotoxin injection $(0.2 \mu \mathrm{g} / \mathrm{kg}$ b. wt.) ( $\boldsymbol{\nabla})$. Two rabbits $(+)$ died during the sampling time, the two others survived.

From the present results it cannot be concluded whether the metabolism of warfarin is decreased. However, it is obvious that a contraction of the distribution volume and a redistribution of warfarin explain the rise of the plasma concentration at the end of the experiment, in the deadly intoxicated rabbits.

Lidocain is the drug which has been studied most extensively in cardiac failure and circulation disturbances in human (Benowitz \& Meister 1976). Under such circumstances the volume of distribution and the clearance of lidocain are decreased. The clearance of lidocain in heart failure is mainly reduced because of the changes in liver blood flow, but also impaired hepatic metabolism appears to play a role. Whether endotoxin will have a direct toxic effect on liver cells, and in that way delay the elimination of warfarin, is not obvious from the present experiments, but such an effect has been indicated for other drugs by results in rats and rabbits (Gorodischer et al. 1976, Ladefoged 
1978). In endotoxin injected animals a reduction of the protein binding of warfarin can be seen (own unpublished results), and a small reduction in protein binding can shorten the half-life of warfarin in rabbits (Ladefoged 1979). The change in protein binding would have an opposite effect on the half-life of a reduced liver blood flow and a direct toxic effect of endotoxin on the liver cells. This might be the explanation for an almost normal elimination rate of warfarin in some of the rabbits at the lowest endotoxin dose level.

In the pigs it was not possible to show any changes in pharmacokinetic parameters with the dose of endotoxin used, and this may be related with a species difference in response to endotoxin as reported by others (Brass 1963, Miert \& Frens 1968).

\section{ACKNOWLEDGEMENTS} ciated.

The technical assistance of Mrs. Gerda Larsen is gratefully appre-

\section{REFERENCES}

Bachmann, K. \& R. Shapiro: Protein binding of coumarin anticoagulants in disease states. Clin. Pharmacokin. 1977, 2, 110-126.

Benowitz, N. L. \& W. Meister: Pharmacokinetics in patients with cardiac failure. Clin. Pharmacokin. 1976, 1, 389-405.

Brass, W.: Die Wirkung von Pyogenen bei Haustieren. (The effect of pyrogen in domestic animals). Proc. 17th Wld Vet. Congr. Hannover 1963, 165-169.

Elin, R. J., E. S. Vesell \& S. M. Wolff: Effects of ethiocholanoloneinduced fever on plasma antipyrine half-lives and metabolic clearance. Clin. Pharmacol. Ther. 1975, 17; 447-457.

Gorodischer, R., J. Krasner, J. J. McDevitt, J. P. Nolan \& S. J. Yaffe: Hepatic microsomal drug metabolism after administration of endotoxin in rats. Biochem. Pharmacol. 1976, 25, 351-353.

Kato, R.: Drug metabolism under pathological and abnormal physiological states in animals and man. Xenobiotika 1977, 7, 25-92.

Ladefoged, O.: Absorptionen fra peritonealhulen. Eksperimentelle unders $\phi g$ gelser over intraperitonealt applicerede lægemidlers farmakokinetik. (Absorption from the peritoneal cavity). Ph. D. Thesis, Copenhagen 1975, $79 \mathrm{pp}$.

Ladefoged, O.: Pharmacokinetics of trimethoprim (TMP) in normal and febrile rabbits. Acta pharmacol. (Kbh.) 1977, 41, 507-514.

Ladefoged, 0. : The effect of $\mathrm{E}$. coli endotoxin on the gastrointestinal absorption of antipyrine in rabbits. Proc. 13th Nord. Vet. Congr. Åbo 1978, 363. 
Ladefoged, O.: The pharmacokinetics of warfarin in hypoalbuminaemic rabbits. To be published 1979 .

Landy, M. \& W. Braun: Bacterial Endotoxins. Quinn and Boden Co., New Jersey 1964.

Miert van, A. S. J. A. M. \& J. Frens: The reaction of different animal species to bacterial pyrogens. Zbl. Vet.-Med. 1968, 15, 532-543.

Song, C. S., N.A. Gelb \& S. M. Wolff: The influence of pyrogen-induced fever on salicylamide metabolism in man. J. clin. Invest. 1972, $51,2959-2966$.

Wolff, S. M. \& J. V. Bennett: Editorial: Gram-negative-rod bacteriemia. New. Engl. J. Med. 1974, 291, 333-334.

\section{SAMMENDRAG \\ Endotoxin inducerede forandringer $i$ warfarins farmakokinetik hos kaniner.}

Warfarins farmakokinetik blev unders $\emptyset$ gt hos kaniner, der fik injektioner af endotoxin (E. coli). Store doser af endotoxin forårsagede chok, og hos kaniner med chok ændredes eliminationen og fordelingen af warfarin. En stor ændring i fordelingsvolumen medf $\varnothing$ rte plasmakoncentrationer, der var højere end begyndelsesværdien. De foreliggende resultater tyder på, at der hos patienter med cirkulationsforstyrrelser induceret af endotoxin kan være risiko for toksiske plasmakoncentrationer eller overdosering af lægemidler efter gentagne doseringer.

(Received February 8, 1978).

Reprints may be requested from: O. Ladefoged, the Department of Pharmacology and Toxicology, Royal Veterinary and Agricultural University, Bülowsvej 13, DK-1870 Copenhagen V, Denmark. 